\title{
EFFECTIVENESS OF EUROPEAN OAK WOOD STAINING WITH IRON (II) SULPHATE DURING NATURAL WEATHERING
}

\author{
Agnieszka Jankowska, \\ https://orcid.org/0000-0002-4827-5949
}

Arkadiusz Kwiatkowski ${ }^{1}$

\begin{abstract}
Artificial graying of wood can be solution for contemporary trends of using uncoated wood for the arrangement of external architecture. The presented work was aimed at investigation of colour changes of European oak (Quercus sp.) wood surface treated with iron (II) sulphate. Three different procedures differing in time $(2 \mathrm{~h}$ and $24 \mathrm{~h})$ and temperature $\left(20^{\circ} \mathrm{C}\right.$ and $\left.70^{\circ} \mathrm{C}\right)$ were used, as well as three different concentrations of aqueous iron (II) sulphate solutions $(10 \%, 20 \%, 30 \%)$. Beside the colour itself, it was evaluated the stained oak wood discolouration due to natural weathering. Thanks to iron (II) sulphate, wood colour changed to dark grey. In general, the colour changes on tangential section of wood were higher than those on radial section what was result of wood structure, in particular parenchyma cells arrangement in wooden rays. Contrary to expectations, the concentration of the iron (II) sulphate solution was not of significant importance for wood staining. Usage of concentrations higher than $10 \%$ for the modification of the colour of wood gives the same effects. However, with increasing solution used to wood staining, the colour stability of the wood decreases during external exposure. The parameters of the procedure were not significantly affected. This allows the application of the simplest and least time-consuming modification method to be considered.
\end{abstract}

Keywords: Artificial graying, colour changes, European oak, iron sulphate, weathering.

\section{INTRODUCTION}

According to the contemporary trends it is recommended to use untreated wood that turns grey after exposure to weather under aboveground conditions (Oberhofnerová et al. 2017). Leaving uncoated wood during external exposition has become popular in modern architecture in order to circumvent frequent maintenance such as repainting (Hundhausen et al. 2020). The decisive element for using different wood species in the harsh outside environment is their durability, in accordance with EN 350 (2016). The usage of renewable natural materials, such as wood, is one of the major contributions to securing sustainable development (Oberhofnerová et al. 2017). In an effort to reduce the ecological burden, the wooden surfaces could be left untreated. In addition to the traditional interior design elements, the use of non-treated wood is expanding even further to external use. Willingness to use of non-chemical treated wood outside force to selection only wood of high durability. Many tropical species are considered to be the most durable wood. However, the use of tropical wood has several negative consequences including illegal deforestation as well as significant impact on climate changes (Swanna et al. 2016). The consequence should be increased interest in the types of wood native to the specific area. Among the European types of wood, the European oak heartwood is characterized by the greatest durability EN 350 (2016).

Wood is highly susceptible to photodegradation, which is mainly ascribed to light absorption by lignin resulting in the formation of aromatic free radicals. As a result of weathering process, wood becomes gray. Photostability of wood surface can be preserved due to some chemical treatments, but graying can only be effectively prevented by applying pigmented exterior coatings (Evans et al. 2015). Despite of the fact that

\footnotetext{
${ }^{1} 1$ Warsaw University of Life Sciences- SGGW. Department of Wood Science and Wood Protection, Warsaw, Poland.
} 
photodegradation occurs rapidly after outdoor exposure, the natural graying process of wood exposed outside can take several years and varies greatly depending on its exposition details, but the greatest intensity of changes is observed at the beginning of external exposure (Evans et al. 2015). Wood parts less exposed to wetting, such as being under a roof overhang, will gray more slowly than those that are more exposed to weathering factors (Evans 2012, Zimmer et al. 2018). According to results of analysis of consumers preferences, the uniformity of the visual surface is desired. Surface-treated wood should not exhibit visual defects from the manufacturing process such as stains (Høibø and Nyrud 2010). Therefore, there is a need to consider the installation of wood with an appearance imitating weathered (aged) wood. In Scandinavia, a popular artificial graying method is treatment with iron sulphate that gradually turns the wood surface colour from artificial into natural graying. In this scope mainly coniferous wood species (such as spruce) were tested (Hundhausen et al. 2020). Darkening wood surfaces is based on the reaction of extractives with polyphenolic structure and metal ions (Canevari et al. 2016). The reaction requires water presence. In the form of hydrolysable tannins, the polyphenolics make up the largest proportion of oak heartwood extractives (Hon and Minemura 2001). The iron-induced stains in oak are gray or blue-black coloured, occurring more frequently in heartwood than in sapwood (Kreber 1994), the most probably due to difference in extractives content in sapwood and heartwood. On the other hand, according to Hundhausen et al. 2020, the dark colour development of the extracted spruce confirmed that any reaction with wood extractives is not necessary for wood colour changes due to treatment with iron (II) sulphate. Discolouration occurs during each contact of wet wood with iron, but certain wood species show particular predisposition. Extractives, such as tannins, interact with iron ions and during exposition to oxygen insoluble iron (III) tannates or pyrogallol complexes and give oak wood a characteristic dark "black oak" colour (Krekel 1999). Similar process is observed naturally in subfossil or bog oak wood which was deposited in rivers, moraine or swamps sediments for hundreds or thousands of years (Machová et al. 2019).

Throughout this work, the perspective was taken that weathering is an option for using untreated wood and creating equal colour settings on its surfaces during external exposition. The presented work was aimed at investigation of colour changes of European oak wood surface treated with iron (II) sulphate as an attempt to verify the usefulness of the method on a wider industrial scale. Beside the wood colour change, another important characteristic is colour stability. Thus, the aim was to evaluate the oak wood discolouration after treatment by iron (II) sulphate and the colour stability of the treated wood during weathering process.

\section{MATERIALS AND METHODS}

\section{Sample preparation}

The research involved heartwood of European oak (Quercus sp. - Q. petraea or Q. robur). The planks for samples preparation were chosen from three different timber stocks. Samples were cut with predominant sepa-

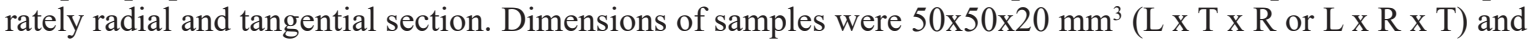
the samples were without any visible defects such as cracks or knots. Each group of 30 samples was intended for different treatment. Prior the experiment began, wood surfaces were planned and sanded (150 grid sanding paper). Such prepared samples were conditioned in dark in standard conditions $\left(20^{\circ} \mathrm{C} \pm 2{ }^{\circ} \mathrm{C}\right.$ and $65 \% \pm 5 \%$ relative humidity).

\section{Iron (II) sulphate treatment}

Iron (II) sulphate was purchased from Chempur, Poland. The solutions were prepared in the laboratory using demineralized water. The scope of the work included wood treatment with aqueous solutions of iron (II) sulphate of three different concentrations $10 \%, 20 \%, 30 \%$ :

- in a short-term cold bath lasting $2 \mathrm{~h}$ at temperature of about $20^{\circ} \mathrm{C}$,

- in a short-term hot bath for $2 \mathrm{~h}$ at $70{ }^{\circ} \mathrm{C}$ and

- in a long-term cold bath lasting $24 \mathrm{~h}$ at room temperature of about $20^{\circ} \mathrm{C}$.

Relatively wide range of modification parameters results from the desire to find the relation between the 
parameters used and the changes induced. After taking samples out from the solution, their surface was washed with water and wiped dry. Treated samples were kept to dry and stored in dark in standard conditions $\left(20^{\circ} \mathrm{C}\right.$ $\pm 2{ }^{\circ} \mathrm{C}$ and $65 \% \pm 5 \%$ relative humidity) until moisture content of wood was stabilized prior to the colour measurement.

\section{Colour testing}

The parameters of the colour of untreated and treated wood were measured on the basis of the mathematical CIE $L^{*} a * b$ colour space models. The CIE $L^{*} a^{*} b$ colour system estimates the value of three variables: coordinate $L^{*}$ for lightness, representing the position on the black-white axis, coordinate $a^{*}$ for the position on the red-green axis and coordinate $b^{*}$ for the position on the yellow-blue axis (Hunterlab 1995). The total colour change $\Delta E^{*}$ was determined in accordance with ISO 7724-3 (1984). The 3 NH NH300 spectrophotometer made by X-Rite Europe $\mathrm{GmbH}$ (Regensdorf, Switzerland) was used to examine the colour parameters. The sensor head diameter was $8 \mathrm{~mm}$. Measurements were made using a D65 illuminate. Parameters $L^{*}, a^{*}$ and $b^{*}$ were measured at 5 points on each sample.

\section{Weathering}

Weathering consisted of placing the samples horizontally in the external environment in the third use class according to the EN 335 (2013) standard "wood or wood-based material is not under a roof and is not in contact with the ground, either it is constantly exposed to the elements, or it is protected from the effects of weather conditions, but subjected to frequent humidification". The exposition took place 136 days - from 2018/07/20 to 2018/12/04 in Poland (52,794811 N; 21,960396 E). Overview of the climatic conditions during weathering can be seen in Table 1 .

Table 1: Summary of weather parameters in the months of weathering (based on data of Institute of +Meteorology and Water Management National Research Institute in Poland (2018)).

\begin{tabular}{|c|c|c|c|c|c|c|}
\hline Parameter* & July & August & September & October & November & December \\
\hline $\mathrm{t}_{\mathrm{av}}\left({ }^{\circ} \mathrm{C}\right)$ & 21,4 & 21,1 & 162 & 10,4 & 4,4 & 1,6 \\
\hline $\mathrm{t}_{\mathrm{max}}\left({ }^{\circ} \mathrm{C}\right)$ & 32,0 & 32,4 & 28,8 & 21,6 & 19,2 & 8,4 \\
\hline $\mathrm{t}_{\min }\left({ }^{\circ} \mathrm{C}\right)$ & 11,4 & 7,7 & 0,0 & 1,9 & $-7,9$ & $-11,8$ \\
\hline Rain $_{\mathrm{t}}(\mathrm{mm})$ & 85,1 & 62,6 & 44,8 & 51,7 & 11,2 & 51,0 \\
\hline$\Phi_{\mathrm{av}}(\%)$ & 68 & 68 & 72 & 78 & no data & no data \\
\hline Ins $(\mathrm{h})$ & 184,3 & 245,1 & 180,4 & 131,5 & 65,6 & 14,8 \\
\hline
\end{tabular}

$* \mathrm{t}_{\mathrm{av}}$ - average monthly temperature, $\mathrm{t}_{\min }$ - minimum monthly temperature, $\mathrm{t}_{\max }$ - maximum monthly temperature, Rain $_{t}$ - sum of monthly rainfall, $\Phi_{\text {av }}$ - monthly average air humidity, Ins - insolation.

\section{Microscopical analysis}

The TPL digital microscope with 2 MPIX and 1/4" CMOS sensor (BRESSER GmbH, Germany) was used in order to generate microscopic images of wood surfaces for the visual assessments. The microscope is equipped with a physical matrix resolution of 1,3 million pixels. The samples were chosen randomly and the analysis was conducted at least in three repetitions for tested samples.

\section{Statistical analysis}

Statistical analysis of the test results was carried out using Statistica v. 13.3 software (TIBCO 2013). Data was analysed and provided as the mean \pm standard deviation. To compare and determine the significance of observed phenomenon analysis of variance (ANOVA) was made at the 0,05 level of significance. The test factors and their variability levels are given in Table 2. 
Table 2: Levels of tested factors in relation to the European oak colour changes.

\begin{tabular}{|c|c|c|c|}
\hline Wood section & $\begin{array}{c}\text { Concentration of the } \\
\text { solution }(\%)\end{array}$ & $\begin{array}{c}\text { Time of treatment } \\
(\mathrm{h})\end{array}$ & $\begin{array}{c}\text { Temperature of } \\
\text { treatment }\left({ }^{\circ} \mathrm{C}\right)\end{array}$ \\
\hline Radial & 10 & 2 & 20 \\
Tangential & 20 & 24 & 70 \\
\hline
\end{tabular}

\section{RESULTS AND DISCUSSION}

\section{Colour changes after iron (II) sulphate treatment}

The oak samples treated with iron (II) sulphate were intensively darker right after the treatment than the untreated reference samples (Figure 1). Wood colour turned immediately dark grey-blue-black after the treatment with iron (II) sulfate as the iron ions reacted with gallic acid to ferrous gallate, which subsequently oxidized to a dark ferric pyrogallate complex (Krekel 1999, Hundhausen et al. 2020). The differences in colour between the applied variants were below the visibility limit.

The average values of coordinates $L^{*}, a^{*}$ and $b^{*}$ for are presented in Figure 1. Treatments reduced the wood lightness by about twenty. The $a^{*}$ and $b^{*}$ values were reduced significantly ( $a^{*}$ from about 10 to about 0 and $b^{*}$ from about 20 to the range 2 to 8 ). Based on total colour changes $\left(\Delta E^{*}\right)$, it can be said that in general the colour changes on tangential section were higher than those on radial section of samples (Table 3 ). ANOVA indicated that temperature and treatment time are another important factor. Contrary to expectations, the concentration of the iron sulphate solution was not of significant importance (Table 4). As the colour change is not influenced by the iron (II) sulphate concentration, it must be concluded that the use of solutions with concentrations higher than $10 \%$ is unproductive.

Table 3: Overall colour change $\left(\Delta E^{*}\right)$ after iron (II) sulphate treatment (mean and standard deviation in parentheses).

\begin{tabular}{|c|c|c|c|c|}
\hline \multirow{3}{*}{ Wood section } & \multirow{2}{*}{$\begin{array}{c}\text { Concentration of } \\
\text { the solution (\%) }\end{array}$} & $\begin{array}{c}\text { After } 2 \mathrm{~h} \\
\text { in } 20^{\circ} \mathrm{C}\end{array}$ & $\begin{array}{c}\text { After } 24 \mathrm{~h} \\
\text { in } 20^{\circ} \mathrm{C}\end{array}$ & $\begin{array}{c}\text { After } 2 \mathrm{~h} \\
\text { in } 70{ }^{\circ} \mathrm{C}\end{array}$ \\
\cline { 3 - 5 } & & $27,60(1,28)$ & $31,12(1,57)$ & $27,39(1,99)$ \\
\hline \multirow{3}{*}{ Radial } & 10 & $27,40(1,18)$ & $29,66(1,58)$ & $28,84(1,24)$ \\
\cline { 2 - 5 } & 20 & $28,95(2,13)$ & $29,27(0,49)$ & $24,61(0,81)$ \\
\cline { 2 - 5 } Tangential & 30 & $31,62(1,53)$ & $33,89(0,58)$ & $30,10(1,41)$ \\
\cline { 2 - 5 } & 10 & $31,38(1,36)$ & $31,02(1,74)$ & $27,43(1,58)$ \\
\cline { 2 - 5 } & 20 & $29,61(1,43)$ & $30,81(0,51)$ & $27,24(0,59)$ \\
\hline
\end{tabular}

Oak wood is characterized by wide and high wood rays composed of the lying parenchyma cells. In the radial section, the rays create a flake, while through the tangential section, the content of parenchyma cells can be washed out with water (Richter and Dallwitz 2019). Taking into account that extractives are considered as those responsible for wood colour changes due to interaction with iron ions, the important issue is location of extractives in wooden tissue. Mostly wood extractives are found largely in the parenchyma (Hillis 1971, Yamamoto and Hong 1989). After removing samples from the solutions, despite rinsing, the washed content could have remained on the wood surface. This effect was not observed on radial sections due to the orientation of the parenchyma cells. On this basis, it should be assumed that the difference in wood colour change on tangential and radial sections will occur in wood with large wooden rays such as other oak species or beech.

ANOVA confirmed that $\Delta E^{*}$ is dependent on temperature and duration of the procedure (Table 4). However, the obtained $\Delta E^{*}$ values differ slightly (Table 3 ). Thus, for implementing the modification, the simplest procedure can be applied. 


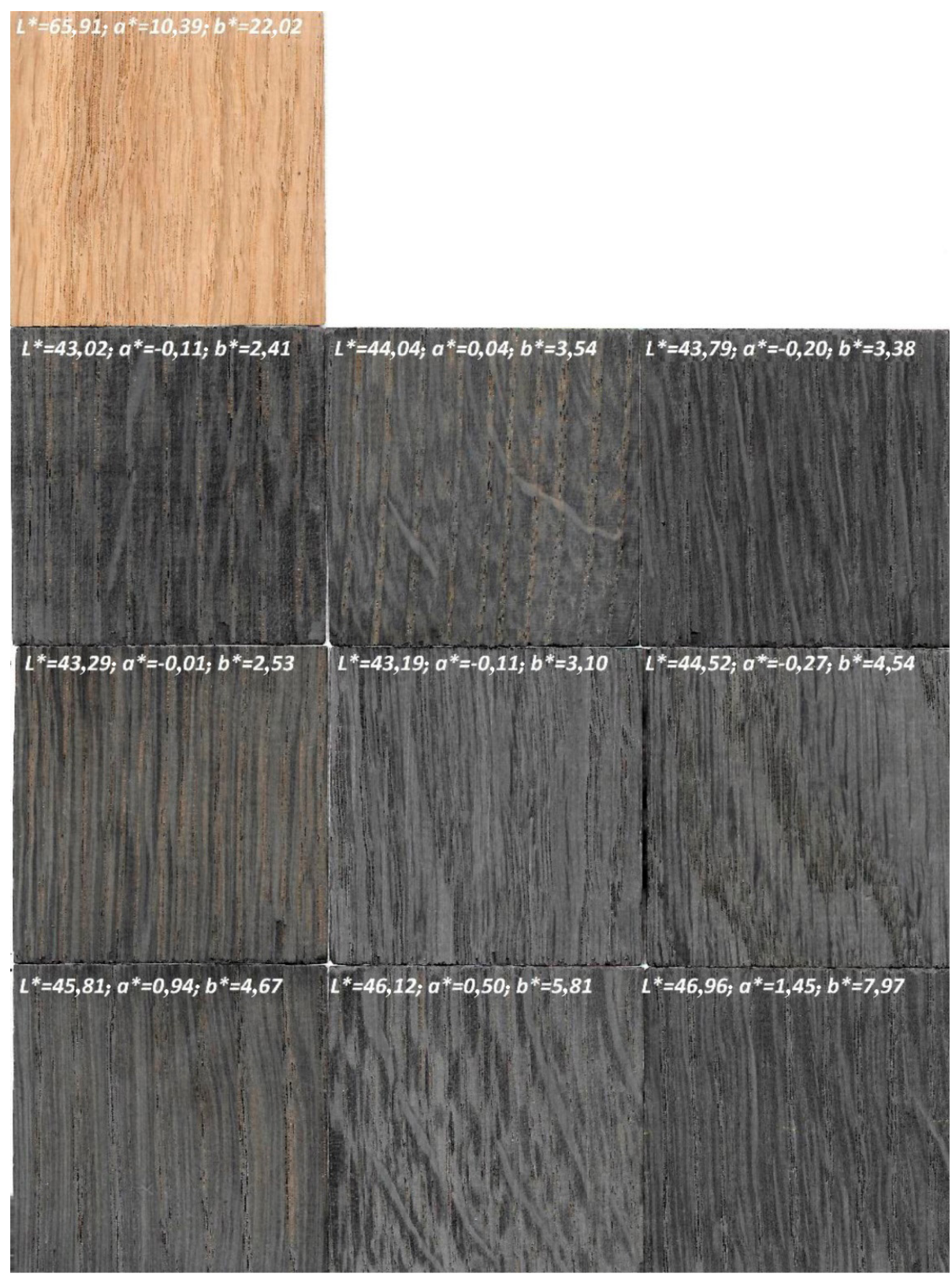

Figure 1: Images of reference wood, and wood treated with iron sulphate: from left to right after $10 \%, 20 \%$ and $30 \%$ solution was applied; from top to bottom: after short-term cold bath $\left(2 \mathrm{~h} ; 20{ }^{\circ} \mathrm{C}\right)$, after short-term hot bath $\left(2 \mathrm{~h}, 70^{\circ} \mathrm{C}\right)$, after long-term cold bath $\left(24 \mathrm{~h}, 20^{\circ} \mathrm{C}\right)$. 
Table 4: Results of ANOVA for the colour parameters after wood staining.

\begin{tabular}{|c|c|c|c|c|c|}
\hline \multirow{3}{*}{ Feature } & Factor & $\begin{array}{c}\text { Sum of } \\
\text { squares }\end{array}$ & $\begin{array}{c}\text { Mean sum of } \\
\text { squares }\end{array}$ & Fisher's F-test & $\begin{array}{c}\text { Significance } \\
\text { level }\end{array}$ \\
\cline { 3 - 6 } & & $\mathrm{SS}$ & $\mathrm{MS}$ & $\mathrm{F}$ & $\mathrm{p}$ \\
\hline \multirow{4}{*}{$L^{*}$} & Section & 2,030 & 2,030 & 1,705 & $0,216053^{\mathrm{NS}}$ \\
\cline { 2 - 6 } & Concentration & 2,732 & 1,366 & 1,147 & $0,349959^{\mathrm{NS}}$ \\
\cline { 2 - 6 } & Time & 5,629 & 5,629 & 4,728 & $0,050390^{\mathrm{NS}}$ \\
\cline { 2 - 6 } & Temperature & 3,520 & 3,520 & 2,957 & $0,111154^{\mathrm{NS}}$ \\
\hline \multirow{4}{*}{$a^{*}$} & Section & 1,749 & 1,749 & 14,389 & $0,002561^{*}$ \\
\cline { 2 - 6 } & Concentration & 0,007 & 0,004 & 0,030 & $0,970350^{\mathrm{NS}}$ \\
\cline { 2 - 6 } & Time & 0,311 & 0,311 & 2,560 & $0,135615^{\mathrm{NS}}$ \\
\cline { 2 - 6 } & Temperature & 0,457 & 0,457 & 3,763 & $0,076278^{\mathrm{NS}}$ \\
\hline \multirow{5}{*}{$b^{*}$} & Section & 3,897 & 3,897 & 3,848 & $0,073414^{\mathrm{NS}}$ \\
\cline { 2 - 6 } & Concentration & 12,320 & 6,160 & 6,082 & $0,014999^{*}$ \\
\cline { 2 - 6 } & Time & 1,297 & 1,297 & 1,281 & $0,279808^{\mathrm{NS}}$ \\
\cline { 2 - 6 } & Temperature & 8,469 & 8,469 & 8,363 & $0,013531^{*}$ \\
\hline \multirow{4}{*}{$\Delta E^{*}$} & Section & 18,486 & 18,486 & 12,760 & $0,003838^{*}$ \\
\cline { 2 - 6 } & Concentration & 10,507 & 5,253 & 3,626 & $0,058644^{\mathrm{NS}}$ \\
\cline { 2 - 6 } & Time & 7,053 & 7,053 & 4,868 & $0,047590^{*}$ \\
\cline { 2 - 6 } & Temperature & 9,990 & 9,990 & 6,895 & $0,022145^{*}$ \\
\hline
\end{tabular}

NS - not significant, * - significant at the 0,05 level.

\section{Colour changes after weathering}

The alternating action of external factors for a period of 4 months resulted in a distinct change in the colour of the wood surface (Figure 2). The colour of the reference wood changed, as did the colour of wood treated with iron (II) sulphate. The total colour change $\left(\Delta \mathrm{E}^{*}\right)$ of reference samples after weathering was averagely 13,46 on radial surfaces and 15,18 on tangential surfaces. The values of $\Delta \mathrm{E}^{*}$ for treated wood samples are given in Table 5 . It should be noted that $\Delta \mathrm{E}^{*}$ of the treated wood changed to a lesser extent than the colour of the reference wood samples in case of tangential surfaces and higher in case of radial surfaces. The anatomical sections turned out to be an important factor determining the colour stability of treated wood during the weathering process (Table 6). As a result of weathering, the tangentially cut samples darkened much more than the radially cut samples. Taking into consideration the structure of wood and the arrangement of particular types of cells, such as parenchyma in wooden rays (Richter and Dallwitz 2019), it can be assumed that the content of parenchyma cells could have been washed out with water from precipitation. The washed content remained on the surface of aged wood. This effect was not observed on radial sections due to the orientation of the parenchyma cells.

During the heartwood process, extractive substances are deposited in the parenchyma cells (including those in the wood rays) (Hillis 1971), which have reacted with iron ions. ANOVA indicated that some parameters describing the colour such as $L^{*}$ (lightness) and $\Delta E^{*}$ were affected by the concentration of the solution used in the course of weathering. As the concentration increased, the colour change due to weathering was greater.

The purpose of the weathering tests was to verify the colour stability of wood treated with the iron (II) sulphate water solution. Thus, for the practical application of the described method, it is not recommended to use concentrations higher than $10 \%$ for the modification of wood colour. 


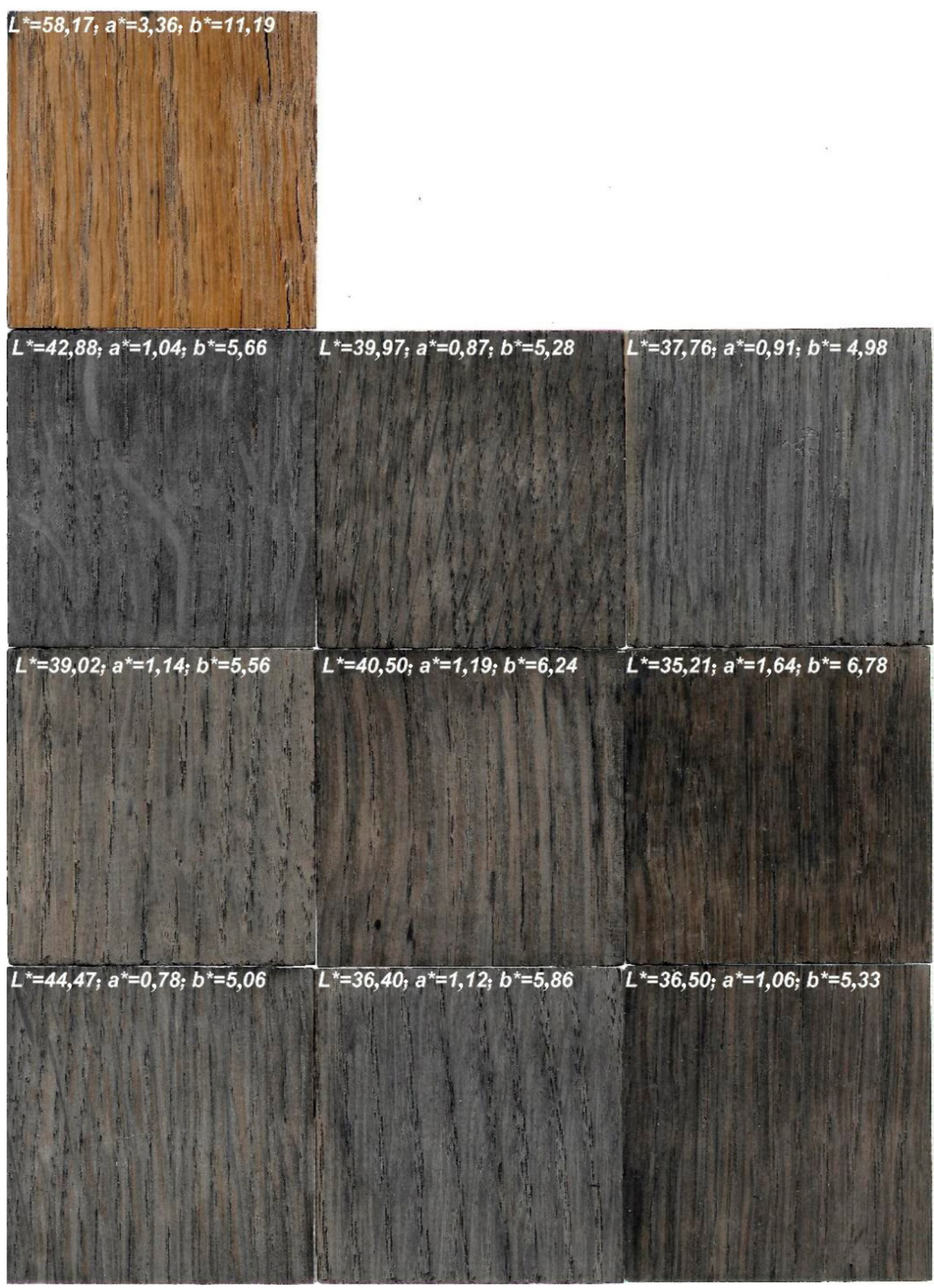

Figure 2: Images after weathering of reference wood, and wood treated with iron sulphate: from left to right after $10 \%, 20 \%$ and $30 \%$ solution was applied; from top to bottom: after short-term cold bath $\left(2 \mathrm{~h} ; 20^{\circ} \mathrm{C}\right)$, after short-term hot bath $\left(2 \mathrm{~h}, 70^{\circ} \mathrm{C}\right)$, after long-term cold bath $\left(24 \mathrm{~h}, 20^{\circ} \mathrm{C}\right)$. 
Table 5: Overall colour change ( $\left.\Delta E^{*}\right)$ after iron (II) sulphate treatment (mean and standard deviation in parentheses).

\begin{tabular}{|c|c|c|c|c|}
\hline \multirow{3}{*}{ Wood section } & \multirow{2}{*}{$\begin{array}{c}\text { Concentration of } \\
\text { the solution }\end{array}$} & $\begin{array}{c}\text { After } 2 \mathrm{~h} \\
\text { in } 20^{\circ} \mathrm{C}\end{array}$ & $\begin{array}{c}\text { After } 24 \mathrm{~h} \\
\text { in } 20{ }^{\circ} \mathrm{C}\end{array}$ & $\begin{array}{c}\text { After } 2 \mathrm{~h} \\
\text { in } 70{ }^{\circ} \mathrm{C}\end{array}$ \\
\cline { 3 - 5 } & $10 \%$ & $3,93(0,94)$ & $5,64(0,92)$ & $4,95(1,55)$ \\
\hline \multirow{3}{*}{ radial } & $20 \%$ & $6,97(1,58)$ & $6,95(1,01)$ & $9,65(1,49)$ \\
\cline { 2 - 5 } & $30 \%$ & $9,74(1,72)$ & $9,43(0,83)$ & $11,23(3,23)$ \\
\cline { 2 - 5 } tangential & $10 \%$ & $18,08(4,41)$ & $12,48(2,05)$ & $19,64(2,84)$ \\
\cline { 2 - 5 } & $20 \%$ & $16,86(1,60)$ & $14,94(2,67)$ & $20,99(3,42)$ \\
\cline { 2 - 5 } & $30 \%$ & $18,98(3,65)$ & $16,04(0,92)$ & $22,10(2,00)$ \\
\hline
\end{tabular}

Table 6: Results of ANOVA for the colour parameters after weathering stained wood.

\begin{tabular}{|c|c|c|c|c|c|}
\hline \multirow{3}{*}{ Feature } & \multirow{2}{*}{ Factor } & $\begin{array}{c}\text { Sum of } \\
\text { squares }\end{array}$ & $\begin{array}{c}\text { Mean sum of } \\
\text { squares }\end{array}$ & Fisher's F-test & $\begin{array}{c}\text { Significance } \\
\text { level }\end{array}$ \\
\cline { 3 - 6 } & & $\mathrm{SS}$ & $\mathrm{MS}$ & $\mathrm{F}$ & $\mathrm{p}$ \\
\hline \multirow{4}{*}{$L^{*}$} & Section & 555,165 & 555,165 & 179,2633 & $0,000000^{*}$ \\
\cline { 2 - 6 } & Concentration & 59,959 & 29,979 & 9,6804 & $0,003139^{*}$ \\
\cline { 2 - 6 } & Time & 3,519 & 3,519 & 1,1363 & $0,307405^{\text {NS }}$ \\
\cline { 2 - 6 } & Temperature & 9,611 & 9,611 & 3,1035 & $0,103553^{\text {NS }}$ \\
\hline \multirow{5}{*}{$a^{*}$} & Section & 2,7541 & 2,75407 & 13,16721 & $0,003459^{*}$ \\
\cline { 2 - 6 } & Concentration & 0,0054 & 0,00273 & 0,01304 & $0,987063^{\text {NS }}$ \\
\cline { 2 - 6 } & Time & 0,73615 & 0,73615 & 3,51952 & $0,085178^{\text {NS }}$ \\
\cline { 2 - 6 } & Temperature & 0,15931 & 0,15931 & 0,76168 & $0,399930^{\text {NS }}$ \\
\hline \multirow{5}{*}{$b^{*}$} & Section & 23,88365 & 23,88365 & 15,44186 & $0,002000^{*}$ \\
\cline { 2 - 6 } & Concentration & 17,72049 & 8,86024 & 5,72855 & $0,057924^{\text {NS }}$ \\
\cline { 2 - 6 } & Time & 4,11353 & 4,11353 & 2,65958 & $0,128877^{\text {NS }}$ \\
\cline { 2 - 6 } & Temperature & 9,01564 & 9,01564 & 5,82902 & $0,032653^{*}$ \\
\hline \multirow{4}{*}{$\Delta E^{*}$} & Section & 486,928 & 486,928 & 119,0128 & $0,000000^{*}$ \\
\cline { 2 - 6 } & Concentration & 51,442 & 25,721 & 6,2867 & $0,013561^{*}$ \\
\cline { 2 - 6 } & Time & 8,467 & 8,467 & 2,0695 & $0,175837^{\text {NS }}$ \\
\cline { 2 - 6 } & Temperature & 10,083 & 10,083 & 2,4645 & $0,142423^{\text {NS }}$ \\
\hline
\end{tabular}

NS - not significant, * - significant at the 0,05 level.

\section{Structure analysis}

Microstructure changes in the wood surface properties were characterized using electronic microscope. Most of the previous conducted studies regard to softwoods. Figure 3 presents images of wood surface before and after surface modification both before and after weathering. The untreated and un-weathered samples indicted cell walls and some easy to recognize damages caused by splitting after mechanical preparation. There was no differences in changes between wood nontreated and treated with iron (II) sulphate. As a result of weathering some characteristic anatomical changes occurred. The weathering treatment caused apparent erosion of wood structure elements. It is also agreed with previous studies of wood surface deterioration after exposure to sunlight or UV irradiation (Srinivas and Pandey 2012). A number of distinctive cracks formed in the samples after exposure to external conditions. In all analysed samples distortion between cell elements and thinning of parenchyma cell walls and their shrinkage were observed. Deterioration was present in parenchyma cells of wood rays. 

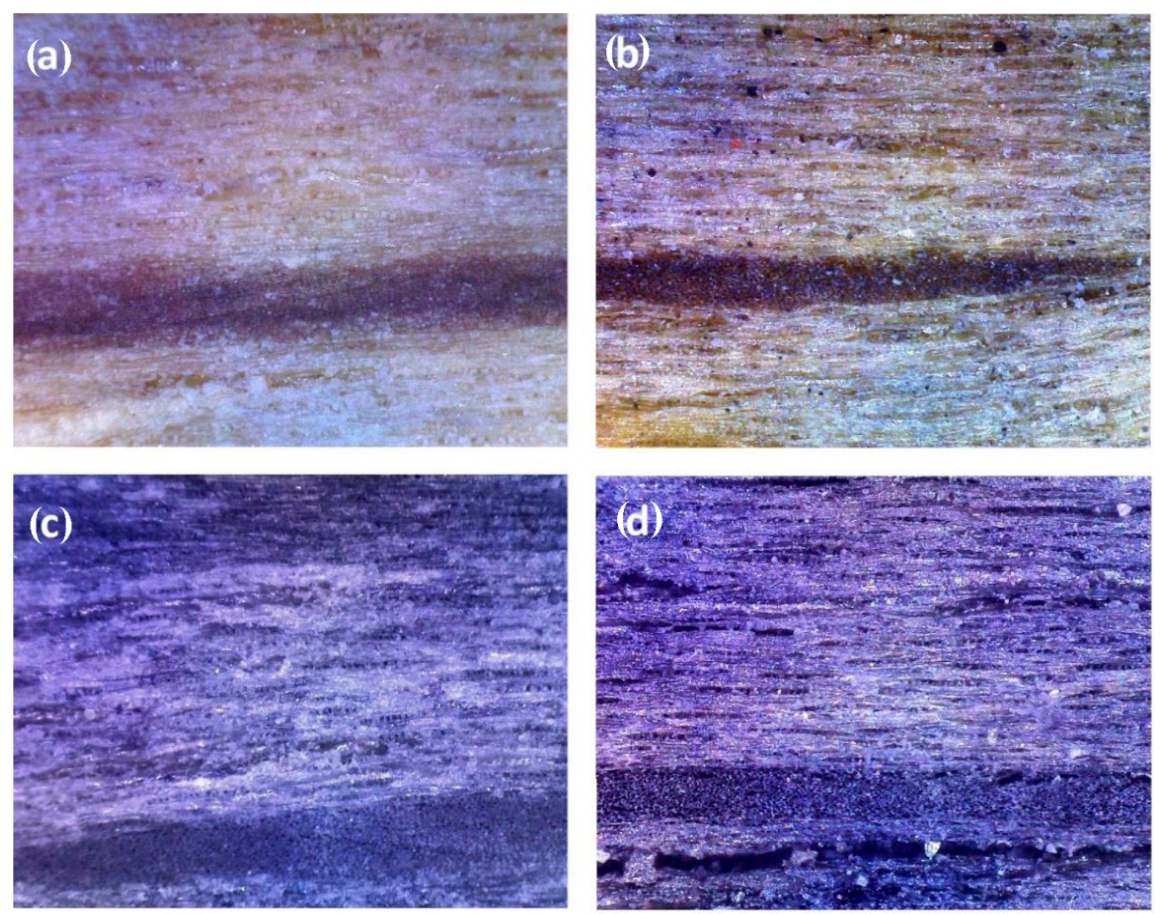

Figure 3: Microscopic images: (a) reference wood, (b) reference wood after weathering, (c) wood treated with iron sulphate, (d) wood treated with iron sulphate and subjected to weathering (magnification 200x).

\section{CONCLUSIONS}

The study explores the colour changes of European oak wood surface treated with iron (II) sulphate. It was an attempt to verify that weathering is an option for using untreated wood and creating equal colour settings on its surfaces during external exposition. Beside the colour itself, the aim was to evaluate the colour stability of the treated wood during weathering process. The oak samples treated with iron (II) sulphate were intensively darker, the colour of the wood changed towards dark gray. In general, the colour changes on tangential section were higher than those on radial section of samples what was result of wood structure, in particular parenchyma cells arrangement in wooden rays. Contrary to expectations, the concentration of the iron (II) sulphate solution was not of significant importance and it also gives the practical implication of our study. By observing the experimental results, it is not recommended to use concentrations higher than $10 \%$ for the modification of the colour of wood. This is also due to the fact that with increasing the used wood staining solution, the colour stability of the wood decreases during external exposure. Anatomical analyses revealed structure changes after weathering treatments such as distortion between cell elements as well as thinning and degradation of parenchyma cells, but no differences in those changes between nontreated and treated ok wood samples were observed.

Overall, the obtained results can be relevant for professionals in building design and construction in line with using of uncoated wood or aged looking wood products. More thorough studies using, e.g., photoelectron spectroscopy suggested to give a deeper insight into the mode of action of iron (II) sulfate on different wood species.

\section{REFERENCES}

Canevari, C.; Delorenzi, M.; Invernizzi, C.; Licchelli, M.; Malagodi, M.; Rovetta, T. 2016. Chemical characterization of wood samples colored with iron inks: insights into the ancient techniques of wood coloring. Wood Sci Technol 50: 1057-1070. https://doi.org/10.1007/s00226-016-0832-2

Data of Institute of Meteorology and Water Management. 2018. National Research Institute in Poland. https://danepubliczne.imgw.pl/

EN. 2013. Durability of wood and wood-based products. Use classes: definitions, application to solid wood and wood-based products. EN 335. 2013. CEN: Brussels, Belgium 
EN. 2016. Durability of wood and wood-based products - Testing and classification of the durability to biological agents of wood and wood-based materials. EN 350. 2016. CEN: Brussels, Belgium

Evans, P.D. 2012. Weathering of wood and wood composites. In: Handbook of Wood Chemistry and Wood Composites. 2nd ed.; Rowel, R.M. (Ed.), CRC Press: Boca Raton, USA. https://doi.org/10.1201/b12487-10

Evans, P.D.; Haase, J.G.; Seman, A.S.; Kiguchi, M. 2015. The search for durable exterior clear coatings for wood. Coatings 5: 830-864. https://doi.org/10.3390/coatings5040830

Hillis, W.E. 1971. Distribution, properties and formation of some wood extractives. Wood Sci Technol 5(4): 272-289. https://doi.org/10.1007/BF00365060

Høibø, O.; Nyrud, A.Q. 2010. Consumer perception of wood surfaces: The relationship between stated preferences and visual homogeneity. J Wood Sci 56(4): 276-283. https://doi.org/10.1007/s10086-009-1104-7

Hon, D.N.S.; Minemura, N. 2001. Color and discoloration. In: Wood and cellulosic chemistry, $2^{\text {nd }}$ edition. Hon, D.N.S.; Shiraishi N. (eds.) Marcel Dekker: New York, USA. https://doi.org/10.1021/ja015237p

Hundhausen, U.; Mai, C.; Slabohm, M.; Gschweidl, F.; Schwarzenbrunner, R. 2020. The Staining effect of iron (II) sulfate on nine different wooden substrates. Forests 11(6): 658. https://doi.org/10.3390/ f11060658

Hunterlab. 1995. Use measurement of appearance. A Wiley-Interscience publication, Wiley and Sons: New York, USA.

ISO. 1984. Paints and varnishes. Colorimetry. Part 3: Calculation of colour differences. ISO 7724-3. 1984. ISO: Geneva, Switzerland.

Kreber, B. 1994. Understanding wood discoloration helps maximize wood profits. In Proceedings of Western Dry Kiln Association Meeting. Portland, Canada.

Krekel, Ch. 1999. Chemistry of Historical Iron Gall Inks. Int J Forensic Doc Examiners 5: 54-58.

Machová, D.; Baar, J.; Paschová, Z.; Pařil, P.; Křenková, J.; Kúdela, J. 2019. Color changes and accelerated ageing in oak wood treated with ammonia gas and iron nanoparticles. European Journal of Wood and Wood Products 77: 705-716. https://doi.org/10.1007/s00107-019-01406-x

Oberhofnerová, E.; Pánek, M.; García-Cimarras, A. 2017. The effect of natural weathering on untreated wood surface. Maderas-Cienc Tecnol 19(2): 173-184. http://dx.doi.org/10.4067/S0718-221X2017005000015

Richter, H.G.; Dallwitz, M.J. 2019. Commercial timbers: descriptions, illustrations, identification, and information retrieval. In English, French, German, Portuguese, and Spanish. https://www.delta-intkey.com/

Srinivas, K.; Pandey, K.K. 2012. Photodegradation of thermally modified wood. Journal of Photochemistry and Photobiology B: Biology 117(5): 140-145. https://doi.org/10.1016/j.jphotobiol.2012.09.013

Swanna, A.L.S.; Longob, M.; Knox, R.G.; Leed, E.; Moorcroft, P.R. 2016. Future deforestation in the Amazon and consequences for South American climate. Agric For Meteorol 214-215: 12-24. https://doi.org/10.1016/j.agrformet.2015.07.006

TIBCO. 2013. Statistica v. 13.3 software.

Yamamoto, K.; Hong, L. 1989. Location of extractives and decay resistance in some Malaysian hardwood species. J Trop For Sci 2(1): 61-70.

Zimmer, K.; Gobakken, L.R.; Flindall, O.; Nygaard, M. 2018. Colour changes in unpainted wooden façades - Fifty Shades of Grey. In: Proceedings of the IRG/WP 49th IRG Annual Meeting. Johannesburg, Republic of South Africa. 